\title{
Moskiewska trylogia Jana Żabczyca
}

Michał Kuran 


\section{Michał Kuran}

\section{Moskiewska trylogia Jana Żabczyca}

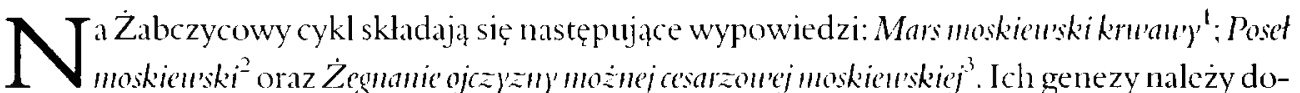
szukiwać się w związkach poety z domem Mniszchów. Jak pokażą dedykacje, krạg osób, którym poeta slużyt, pisząc propagandowo-panegiryczne komunikaty, ogranicza się do trzech postaci bezpośrednio zaangażowanych w awanturę̧ moskiewską: Jerzego Mniszcha oraz jego dzieci - Stanislawa i Maryny. Czwartą osobą zajnująca poczesne miejsce w Zabczycowej trylogii był, oczywiście, sam 1)ymitr I Samozwaniec. Picrwszy utwór zostal opatrzony dwiema dedykacjami; jedną skierował autor do Jerzego Mniszcha, wojewody sandomierskiego, następnie umieścil wiersz Na herb Zicmie Moskicwskiej, by druģ dedykację poświęcić Dymitrowi Iwanowiczowi - Samozwańcowi. Kolejny utwór przypisał Zabczyc Stanisławowi Mniszchowi, starościc sanockiemu, synowi Jerzego; trzeci, Żegnanie ojczyzny, nie zostal opatrzony dedykacją, natomiast pierwszoplanową postacią stała siç wyruszająca do Muskwy „caryca" Maryna.

W Żabczycowej trylogii do glosu dochodzą wszystkie nadzicje, jakie wiązano w Rzeczypospolitej z osobą Dymitra. Nie chodziło tu może tylko o militarny podbój sąsiedniego państwa, choć ten motyw ujawnił się zarówno w Marsic moskieuskim, jak i w Żegnaniu ojizyzmy, lecz o korzyści materialne, jakie mogły uzyskać osoby zaangażowane w to przedsięwzięcie. Po części liczono równicż na przybliżenic unonnowania stosunków z ważnym sąsiadem poprzez nie tylko dominację militarną, ale także wlączenie domu tam panującego w sieć wzajemmych powiązań rodowo-dynastyczno-sąsiedzkich. Zarówno Zygnunnt III Waza, jak też

1. Żabczyc, Marsmoskien'skikrn'un')' Kraków, w druk. Mik. Szarffenbergera. 1606. k. 1-4; A-E4 (cgz. Bibliotcki Uniwersyteckicj w Warszawie, sygı. BUW 4.2(0.4.4.96).

= Idem, Puset moskicuski, Kraków. w druk. Mik. Szarffonbergera, 1606, k. A-BH4 (cgz. BUW. sygn. 2414).

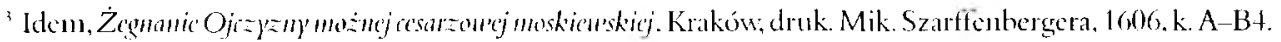


polscy i litewscy politycy oraz po części szeroko pojęta opinia publiczna Rzeczypospolitej spodziewali się osiągnięcia licznych korzyści ze związku cara moskiewskiego i polskicj szlachicianki. Nadzieje te doszly do glosu także w poematach Żabczyca. Poeta utrwalił w pamięci historycznej i literackiej nie tylko ciąg zdarzení, które nie wieszczyły bliskiej przecież tragedii, lecz przeciwnie, zdawaly się zapowiadać szczęśliwy rozwój relacji polsko-moskiewskich $^{4}$. Żabczyc podjąl próbę artystycznego przedstawienia zdarzení, by poprzez swoją sztukę upowszechniać wiedzę o nich. Samej więc publikacji, jak tez wznowieniu ${ }^{5}$ krótkich, ulotnych wypowiedzi przyświecał cel informacyjno-popularyzatorski, propagandowy i panegiryczny. Chodziło między innymi o przckonanic opinii publicznej do sluszności interwencji moskiewskiej oraz o promocję zadluzonego, ale mającego wielkie aspiracje domu Mniszchów". Bliski związek poety z czolowymi przedstawicielanni domu podnosi wartość Zabczycowej relacji o zdarzeniach, należy bowiem przyjąć, że poeta ściśle reprezentował interesy swoich mecenasów, to jest przedstawiona przez niego wersja zdarzeń zgodna była z propagandowymi potrzcbanil Mniszchów.

Obok słów nadziei związanych z ponyślną realizacją przedsięwzięcia do głosu doszedı także negatywny stereotyp wschodniego sąsiada. Moskwa była postrzegana jako kraj stabo rozwinięty, dziki, zacofany, w którym panowaly grubiańskie obyczaje, rządzila podejrzliwość, na porządku dziennym były polityczne morderstwa, okrucieństwo, brak szacunku dla panujących. Świadectwem tego przywołana w skrócie, ociekająca krwią najbliższych, biografia młodego Dymitra, rodem jak z powieści kryminalnej, w której obok zabicia skrycie w lóżku następcy tronu (zginąc mial nie Dymitr, lecz podobny do niego inny młodzieniec) ${ }^{7}$, mamy przykłady otrucia i tragicznej śnierci Borysa (iodunowa oraz jego rodziny. Dlatego nie może dziwić, iż pożegnaniu Maryny i jej ojca wyjeżdżających do Moskwy towarzyszyly następujące słowa podyktowane obawą o bezpieczeństwo wyruszających, a także wyrażające stereotyp:

Jedzie pan baczny, dom swój opuszczając,

[Zonę i dzieci, powinnych żegnając,

Będąc w wiek zaszłym, a źrzebca ujeżdża,]

Na plac wyjeżdża.

Spokojny, pałasz na zly bój dobywa,

A zdradnej Moskwie wosoce okrywa,

Siecze, morduje, czyniw zdrajcach szkody, Juzjako młody (Żegnanic ojcz)zn, k. A 2; podkr. M. K.)

\footnotetext{
${ }^{4}$ Por. II. Wister, ZYgmumt III I Liza. Wroctaw 1991, s. 111.

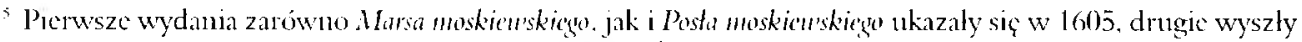
w roku mastępnym. Por. M. P'iszczkowski. Pisma Jama Zaboz) La. Lów 1937. s. 11 [283].

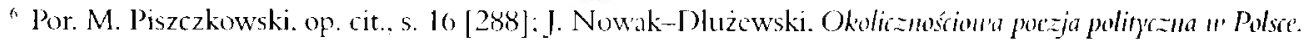
Zygmmin III, Warszawa 1971.s. 190.

${ }^{7}$ Por. szczególy: I. Nowak-Dlużewski, op. cit., s. 191. Badacz shusznie zauważyl. iz moskiewskie zdarzenia „musialy budzié cickawość polskich czycclników niczwyklością tróści i wypadków. [...] Bylo to swojski romans awanturniczy: którçgo publiczność lakıç̣ta".
} 
Nie są to słowa świadczące li tylko o obywatelskicj odwadze i determinacji Jerzego Mniszcha, wynikających z chęci poprawienia swojej katastrofalncj sytuacji naterialnej, ale potwierdzające obecność w polskiej świadomości spolecznej negatywnego stereotypu Rosjanina i Księstwa Moskiewskicgo. Potwierdzenie tego stereotypu obecne jest także w siódmej księd ze Kroniki Sarmacyjej coropskicj Alcksandra Gwagnina oraz w innych tekstach późnicjszych i weześniejszych (na przykład Whad)'stau' IV k kól polski iszu'edzki Sammela Twardowskiego).

Trylogii moskiewskiej Żabczyca nieco uwagi poświęcil w monografii twórczości poety Mieczystaw Piszczkowski. Badacz nie dostrzegl specjalnych walorów artystycznych w zróżnicowanym literacko cyklu poety, wyrzekał na rwące się w Marsio moskie'uskim zdania, dostrzegt jednak poprawę stylu w dalszych częściach trylogii, negatywnie ocenial eksperymenty językowe poety, który zgodnic z modą swoich czasów lubował siç w tworzenitu przymiotnikowych i rzeczownikowych form złozonych typu "mylnobiegle”, "krwawomord”. Badacz ponadto skonstatowal zgodność warstwy historycznej z faktami oraz sformutowal przypuszczenic o propagandowym celu napisania tekstów. Oczywiście prawdziwe są informacje traktujace o zdarzeniach począwszy od pojawienia się Dymitra na dworach panów polskich, choć przedstawione tendencyjnie, natomiast opowieść o jego młodości to juz, rzecz jasna, wytwór wyobraźni samego mlodzicúca bądź propagandowy produkt jego protektorów.

Żabczycowy cykl omówił w swej Okolicznościoneci poezii polityenejej Juliusz Nowak-Dłuzewski. Obok prezentacji treści utworów badacz sformutowal kilka uszczypliwych uwag o charakterze wartościującym "Z Zegnaniem ojczyzny zajęla się natomiast Teresa Banasiowa analizujaca wypowiedź poety jako przykład realizacji konwencji lamentu"'.

Jako źródlo historyczne trylogię Zabczyca wykorzystala Danuta Czerska w monografii Dymitra Samozwańca oraz Henryk Wisner charakteryzujący panowanie Zygmunta III Wa zy ${ }^{\prime \prime}$. Do wcześnicjszych wyczerpujących prac poświęconych Dymitriadom, w których sięgano po materiat historyczny zgromadzony przez poetę. należy cykl obszernych opracowań Alcksandra H lirschberga ${ }^{2}$. Warto przy tej okazji zauważyc, ze Zabczyc budował swoje wypowicdzi, czerpiąc informacje o zdarzeniach z relacji posłów oraz przywozonej przez nich z Moskwy korespondencji. O takich źródlach pozyskiwania wiadomości na temat wypadków w Moskwie informowal poeta w Ż'gnanin ojcz'zn'), gdy rozprawiat siç z przeciwnikami Muiszchów.

\footnotetext{
"Hor. tez illidem, s. 191.

"Mridem, s. $189-198$.

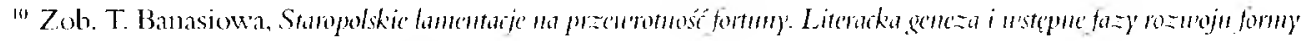
gammkourej, w: Staropolskie teksty i komeksty. t. 3. red. J. Malicki, Katowice 1997, s. 62-67.

$"$ Zob. H I. Wisner, ZX'gmmm III lliza. s. 111.

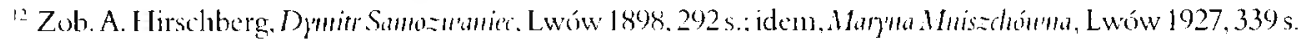




\section{Mars moskiewski}

W Marsie moskicuskim sięgnąl autor po konwencję epiki bohaterskiej, już w pierwszych wersach parafrazując początkowe zdania Encidy' Wergiliusza, zaś Dymitra upodabniając do mitycznego Eneasza ${ }^{13}$ :

Dzieje i męża powiem, htóry z cudzej strony

Przyjechal i dosiągal od Lachów obrony;

Igrzyska powtarzając Marsowe, a zdroje

Zc krwią zmieszal, tarbując posoką pokoje,

Mroźny kędy naczęścicj Boreas przebywa,

A w ryfejskich padolach swe biegi zakrywa (w. 1-6, k. A).

Dyınitr jawi się jako wędrowiec-wygnnaniec, który uzyskal wsparcie od Polaków w walce o swojc prawo do korony moskiewskiej. Upodabniając go do Encasza chcial pocta stworzyć wrażenie, że magnaci ruscy (książęta Adam i Konstanty Wiśniowieccy) oraz Mniszchowie (Jerzy i jego syn Stanisław) udzielili wsparcia wygnanemu z ojczyzny tulaczowi, któremu slusznie się należał tron moskiewski. Tworząc epicki nastrój, Żabczyc odwołał się do pozytywnych odczuć, jakie w odbiorcy budzila osoba i los Eneasza, by przenieść je na Dymitra.

Wprowadzenie w specyfikę problematyki moskiewskiej stanowila następująca zaraz po introdukcji bohatera charakterystyka fauny i flory oraz warunków geograficzno-klimatycznych krainy, którcj dotyczyła epicka opowieść. Wśród śniegów, w dạbrowach, w zimnych jaskiniach żyły wilki, zające, niedźwiedzie, sobole, lisy i dzikie konie, ludzcy mieszkańcy zaś zaslużyli na to, by nazwać ich ,zlym ludem” ( $k$. A $\bullet$ ), ponieważ uczynili swym whadcą „Borysa zdradnego", czyli Borysa Godunowa ${ }^{1+}$.

Wstęp do właściwej tematyki opowieści polączyl pocta ze zwroten do Muz:

Wy o tym dobrze wiccic, Muzy, które swoje

Macie w tamtecznych gmachach ciekoplynne zdroje.

Same wy dzisia, same BASILIDA sprawy

Wspominajcie: dzielności, dom, potomstwo, sławy;

Zacne, gdy lata trawil, splodzil równe sobie

Dzieci: Fedora, DMITRA, Iwana [...] (k. A r.).

Żabczycowa relacja, wychodząca od uwag na temat Dymitrowego ojca, jego rodzeństwa i dalszych losów braci Fiedora i Iwana, koncentrowala się na osobie głównego bohatera. Jego losy determinują kierunek rozwoju akcji.

Odwołanie do własnych Muz, jak też potwierdzenie epickiego charakteru podjętego przedsięwzięcia z powolaniem się wręcz na autorytet Homera, wprowadził autor nieco dalej,

\footnotetext{
'Por. M. Piszczkowski, op. cit. s. 11-12 [283-28+1. ]. Nowak-Dhuzewski uznał mylnie ów początek urworu

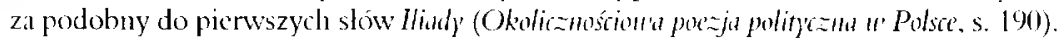

${ }^{1+}$ Por. tcż M. Piszczkowski. op. cit.. s. $12|28+|$.
} 
przed opisem porządku wojska wyruszającego do Moskwy po to, by osadzić na tronie samozwańczego cara:

A wtym myślić zaczęli, jakoby Dziedzica

Odprowadzić do Moskwy. Tu juz nic z moj sicly,

Jakowe tam rycerstwo i wyprawy byly,

Sam by tu Homerus potrzebien (ten Troje

Walki pisał przeważne), az by Muzy moje

Twardą skatę rozbiły, tamżc pokazały,

Rachunek ludzi znacznych, mnic do rąk podały,

Opisałbym rycerstwa, dzielności i sprawy,

Podam jednak mym piórem, krwią nabyte slawy [...] (k. C 3).

Poeta stwierdzil, że material epicki jest dostateczne obfity, by napisać druga lliade. Do rèalizacji takiego zamysłu potrzeba jednak drugiego Homera, natomiast możliwości literackie autora, wedlug jego oceny, nic byly aż tak duze, by mógl pozwolić sobic na rozmach równy antycznemu aojdzie. Stąd też konieczność ograniczenia planów. Trudno zresztą, by same Muzy uderzaly w skałę Helikonu. By wytrysnęło z niej źródlo wody dającej natchnienie, potrzeba Pegazowego kopyta. Zatem poeta, być moze nieświadonie, wbrew nitologii, domagając się od Muz rozbicia skały w poszukiwaniu wody natchmienia, ujawnil, że nie jest w stanie podolać wyzwaniu równemu temu, które podjął I Iomer. Postanowił zarazem ograniczyć swój zamysł do przedstawienia samych zdarzeń.

Porzucenic rozmachu porównywalnego z Homerowym przynioslo pozytywne rezultaty: pozwolilo skondensować informacje zawarte w przekizie, zmusilo autora do lapidarności. Jej przykładem jest opis walki:

1)ali znać do obozu, że nieprzyjaciele

Do taboru się biorą, swoim ludem śmiele.

Jęli na trwogi trąbić, w tym bitne piechoty

W placı stanlęli zaraz; póki by się roty

Nie wyprawili w pole; zatym harcownika

Wypuścili na harce, a wtym kommonnika

Stanowić jęli w polu; pozad jego dziala

Sporządzili burzące; przez ten droga trwała.

Któraby była swoich, nic nie szwankowata,

A harcem przywiedzionych, niezośnie psowala. (k. D $3 n-$ D) 4)

Oszczędność słowa ımożliwila znaczne ograniczenie rozmiaru wypowiedzi, otworzyła droge do sformułowania komunikatywnego przekazu sytuıjącego się na pograniczu nowin, panegiryku, lecz zrealizowancgo z uwzgględnieniem reguł, jakie stawia się epice bohaterskiej, w tym wypadku osnutej na nici biograficznej. 
Mars moskicuski, jako próba epicka nicwiclkich rozmiarów, stanowi przykład małego eposu biograficznego ${ }^{15}$. Ten nadrzędny zanıysl pozwolił również jednak realizować inne cele, przede wszystkim propagandowe. Charakter taki zyskała pierwsza część opowieści upowszechniająa korzystną dla Dymitra Samozwańca wersję jego domniemanych losów od narodzin do „cudownego” odnalezienia się, z opisem także domnicmanej śmierci carcwicza i wyjaśnieniem tcgo, kto wówczas rzekomo zginąć miał naprawdę (podobny do carewicza chłopiec, który spal z nim razem w jednym lóżku) i co stalo się z cialem zamordowanego. Następnie Zabczyc zrelacjonował z pewnościł prawdziwe dzieje bolnatera od momentu jego „cudownego” odnalezienia się w Rzeczypospolitej, poprzez zabiegi, jakie podjąl, by zorganizować z Polski zbrojną wyprawę po carską koronę. Tę część opowieści kończy epizodyczna relacja o próbic zamachu na zycic Dymitra jeszcze na terenie Rzeczypospolitej. Poeta przedstawił następnie w skrócie przebieg dzialań wojennych, nie ponijając także wydarzeni trudnych w trakcie akcji wojsk polsko-litewskich. Zwieńczenie relacji Zabczycowej stanowi krótkie sprawozdanic o koronacji bymitra i objęciu przez niego rządów. Wydarzenic to poprzedzone zostalo stwierdzeniem śmicrci Borysa Godunowa oraz informacją o zatruciu jego rodziny. Zgon pantuącego otworzył pretendentowi droge do korony. By można było jednak w petni upewnić odbiorcę w przekonaniu o prawym pochodzeniu carewicza, potrzebne bylo potwierdzenie jego tożsamości przez matkę. W celu usankcjonowania wladzy Dymitra carowa została sprowadzona z wygnania z odleglej pólnocy, zaś Samozwaniec miał oddawać jej hołdy, idąc na przykład pieszo koło karety, w której jechała. Poeta nie zapomniał odnotować, ze pierwszemu spotkaniu carowej z Dymitrem towarzyszyl placz „syna” i pocicszanic go przez „matkę".

W strukturze Zabczycowej relacji, jak wspommiano, zwraca uwage lapidarność przekazu, którego celem byla popularyzacja sukcesu nie tylko samego Dymitra, ale przede wszystkim udzialu polskich wojsk $w$ interwencji na terenie sąsiedniego państwa. W części bowiem poświęconej przebiegowi akcji zbrojnej usoba Samozwańca zeszla na plan dalszy, zaś autor skoncentrował się na działaniach wojsk Rzeczypospolitej. Uhonorowaniu polskich uczestników moskiewskiej interwencji służył typowo epicki przegląd oddziałów biorących udzial w kampanii umieszczony zaraz na początku relacji o jej przebiegu (k. C 3-D). Wymieniono między innymi nazwiska niektórych uczestników walk: Stanisława Gogolińskjego, Żulickiego, Dworzyckiego, Bilińskiego, Sczuki, Gunowskiego, Konnickiego, Ratomskiego, Kielcewskiego, starosty sanockicgo, czyli Stanisława Mniszcha, syna Jerzego i brata Maryny, oraz Siecińskiego. Dość często powracalo nazwisko podanego tu na pierwszym miejscu Stanisława Gogolińskiego. Być noże wielokrotne pojawianie się tej postaci nie by ło przypadkowe, lecz wynikało z zamiaru szczególnego uczczenia osoby. Na pewno przecież specjalnie uhonorować postanowil Żabczyc nie tylko samego Dymitra, ale również jego protektorów Mniszchów oraz szcze-

"J. Nowak-[)huzewski (op. cit.. s. 190-191) zaklasytikowal tekst jako .prozaiczną kronikę karicry życiowej Dymitra, ubraną w wicrszowaną fornç". Trudno zgodzić siç z badaczen. zważywszy na bardzo silne sygnaty potwicrdzające epickość zamysh pocty: 
gólnie otoczyć szacunkiem Zygmunta III Wazę, który jako władca, uosabiający słońce - centrum sarmackiego mikroświata - zezwolil na podjęcie operacji moskiewskiej.

Kondensacji przekazu, zwhaszcza w części przedstawiającej przebieg dzialaí wojennych, służyło wprowadzanie krótkich, czasani wręcz lapidarnych wypowiedzi bohaterów:

Czar Dymitr począł wolać na rycerskie pany:

.Dzieci, komu dziś pachnie znaczna polska sława,

Niech się pokaże jego do szturmu wyprawa",

Czego wszyscy Polacy słusznie się zbronili,

Bo podobne przystępy do murów uie byli;

A on ją̧ ich sromocić: „Nie takiemem sobie

Obiecowal pomocy. po was, tęż ozdobie

I slawie cześć dajecie". Na co rozrzewnienii

Lachowie jęli mówić: „Chcesz, by poginieni

Chybcy byli Sarmatae? - zginą!!" Wtym krzyknęli,

„Do szturmu, kto ochotszy!”, i tak się cisnęli (k. D 2).

Miejsce na dhużzze oracje w Marsie moskieurkim znalazł autor jedynie w opisie spotkania Dymitra z Zygmuntem III Wazą (k. B 4-13 4 1.; 36 wersów). Picrwszą byla odpowiedź króla udzielona „carewiczowi”. Jej umieszczenie świadczy o szczególnym szacunku, jakim Mniszchowie, protektorzy pocty, otaczali króla. Wypowiedź ma charakter w dużej mierze filozoficzno-ontologiczny. Whadca snul refleksję na temat przemijania, zmicmuości losu, by w konkluzji swoich rozważań wyrazić zgodę na udzielenie poparcia Sannozwańcowi. Kolejną orację stanowila odpowiedź Jerzego Mniszcha — uniżone podziękowanie za zlecenie właśnie jemu misji moskiewskiej, choć można było ją powierzyć co najmniej kilku bardziej godnym osobom, na przykład hetmanom (k. C-C r.). Wprowadzenie oracji króla, jak i wojewody sandomierskiego miało na celu podkreślenie udzialı wspomnianych osób w szczęśliwym osadzeniu na tronie Dymitra Samozwańca I. Równie propagandowy wydźwięk dotyczący postawy wojsk polskich na terenie Wielkiego Księstwa Moskiewskiego miała informacja o zwróceniu przeciwnikowi cial zabitych żołnierzy:

Rano zaś miłosierdzie Polska pokazała

Krnąhrnej Moskwie, ciała ich ziemi oddawata;

Obyczaj krześcijański wznawiając, w ogromnej

Krainic [...] (k. E I

O zamiarze madania relacji epickiego charakteru świadczy wiçc wprowadzenic toposu Muzy, upodobnienie początku relacji do pierwszych słów Eneidy, powołanie się wprost na Homera, jednoznaczne wskazanie głównego bohatera i towarzyszący mu wybór biograficznego modelu eposu z wyraźnym oznaczeniem początku i końca, a wiẹc od narodzin Dymitra po osiągnięcie korony moskiewskiej; oraz, ze spraw już drobnicjszych, prezentacja oddziałów wyruszających do walki, poetycki opis zmagani z uwzględnieniem zaslug konkretnych ryce- 
rzy, oddanie dramatycznego przebiegu walk, unieszczenie krótkich pobudek wypowiadanych przez wodza do rycerzy. Zanystowi epickiemu towarzyszył cel zarazem informacyjny, jak i panegiryczny. Poeta napisal więc mały epos poświęcony aktualnym zdarzeniom, doprowadzając relację niemalze do ówczesnego realnego „dziś”. Poshużyl się wzniosłą formą epicką, by oddać sarmackiemu odbiorcy tekst sprawiający jednocześnie wrażenie pisanego dla przyszlych pokoleń, zarazem, być może przede wszystkim, wpisujący się w konwencję poetyckich nowin o aktualnych zdarzeniach, realizujący takze cele perswazyjne (propagandowe) i panegiryczne, jak zjawisko określil Juliusz Nowak-Dłuzewski, tekst .,tworzący dość zręczną powieść awanturniczą" "16.

\section{Poset moskiewski}

Utrzymany w wysokim tonie poemat przedstawiający przebieg wizyty posla moskiewskiego w Rzeczypospolitej, który przybyl jako wystannik cara Dymitra, stanowi drugi clement Zabczycowej trylugii. Do Posta moskicuskicyo, pisanego podobnie jak Mars moskicuski trzynastozgłoskowcem rymowanym parzyścic, dolączył autor ujętą w strofy safickie Pobudk"z boginn! Twórca nie skoncentrował się, jak poprzednio, na osobie Dymitra, lecz postanowil szczególnic uhonorować dom Mniszchów, kicrując swoją uwagę na misje posla, którym był Afanasij Własiew, polegającą na poślubieniu w imieniu cara Maryny, córki Jerzego Mniszcha i zarazem siostry Stanisława, któremu autor zadedykował utwór. Specjalnej pochwale Dymitra poświęcil poeta wspomnianą Polundk̨̧ bogimna. Nadrzędnym celem Posta moskiéu'skiego stało się przedstawienie przebiegu wizyty posla cara Dymitra do Rzeczypospolitej po rękę Maryny Mniszchówny od jego przyjazdu, do momentu opuszczenia granic szlacheckiego państwa, tak więc utwór ma charakter sprawozdawczy.

W strukturze wypowiedzi obok stów podmiotu auktorialnego kierowanych do posła znaczące miejsce zajmują przytoczone mowy carskiego wysłannika do Jerzego Mniszcha, króla Zygmunta III Wazy oraz odpowiedź wladcy udzielona Własiewowi. Istomą cząstkę calości stanowią dokumentujące przepych opisy darów skladanych w imieniu cara kolejno Jerzemu Mniszchowi, Zygmuntowi III Wazie, Marynie, jej matce i babce - tym ostatnim dopiero po ślubie per procura. Centralne miejsce zajnuje opis samych zaślubin oraz wesela z uwzględnieniem uczestników uroczystości, darów, rozmieszczenia gości za stolem, krótkiej wzmianki o tańcach, w których udział wzięli król i królewicz Whadyslaw Waza. Dopełnienie relacji o pobycie posła stanowi pochwała Mniszchów, dziçki którym Rzeczpospolita miala zyskać cennego sojusznika na wschodzie; oraz uświadonienie wysokicj rangi splendoru, jaki stal się̧ udzialem rodzin magnackich spokrewnionych z Maryną. Nowy sojusz należalo wykorzystać jako kartę przetargową w zmaganiach ze Szwecją. Calość dopehnia etykietalne przekazanie darów przez króla carskicmu wystannikowi, jak też informacja o zleceniu posłowi za pośrednictwem gońca pozostania w Krakowie na ślubic Zygmmnta III z arcyksiçżniczką Konstancją

16. J. Nowak-Dlıżowski. op. cit., s. 192. 
Habsburżanką. Jak wiadomo w wydarzeniu tym nie wziçła ıdziahı Maryna, która opuściła demonstracyjnie Kraków, udając się do Prądnika ${ }^{17}$. Ostatnie slowa poematu przyniosły krótką wzmiankę o odprawicniı posła przez króla.

Ponicważ Poselstuo traktıje o problematyce zaślubin, można by przypuszczać, że poemat należy zaliczyć do kategorii epitalanniów, razem z innymi wypowicdziami upamiçtniającymi polską część zaślubin Maryny z Dymitrem, i usytıować obok takich utworów, jak cykl ks. Stanisława Grochowskiego Pieśni na fest urieszny u'ielkim dwiema narodom polskiemu i moskien'skiemu oraz Jana Jurkowskiego Iymenaeus Najaśniejszego Monardh' Dymitra Iu'anou ica ... i Najaśnicjscej Panicj... Marymic Carou'ej Moskicuskiej, które niewątpliwie reprezentują wsponniany gatunck $^{18}$. Nic można jednak tak postąpić, gdyż autor wysunąl na pierwszy plan nie sann obrzęd zaślıbin, lecz misję poselska, która do uroczystości doprowadzila, a więc zakończyla się powodzeniem. Rzecz traktuje przede wszystkim o przyjęciu posła w Rzeczypospolitej, przebiegu jego misji, jak też pośrednio o etykiecie dworskiej i kształtowaniu stosunków międzynarodowych. Same zaślubiny, przccicż tylko per procura, schodzą na plan dalszy, sytuując się pomiędzy kolejnymi spotkaniami posła z ojcem narzeczonej, później, jak wspomniano, także z samym monarchą. Na plan picrwszy wysuwają siç za to zabiegi dyplomatycznc oraz, co ciekawe, zyywe opisy darów, które posel skladał w innieniu swego pana polskim dostojnikom i swej przyszlej żonie, jej nieobecnej podczas uroczystości matce, a także reprezentującej ja babce. Zabczyc, podobnie jak niespełna piętıaście lat później Samuel Twardowski w Przeu'ażuj legacyi, rozsmuł przcd czytelnikiem wizjẹ piçknych i drogich przedmiotów, które odbierali polscy dostojnicy. Jego relacja nie stanowi zaledwie suchego spisu darów, przynosi także ich charakterystykę, raz mniej, raz bardziej szczególową. Autor nie zwrócił uwagi na to, że liczba i wartość podarków nie byla ściśle dostosowana do godności otrzyınujących je osób. O ile więc Mniszech dostal konia tarantowatego, zlotą buławę, takąż czarę wysadzaną perlami, zloty lańcuclı, zegar osadzony w krysztale, dwa kobierce, dwa noże w bogatej oprawie oraz nieodlączne futra, a więc kożuch marmurkowy, szlyk, sześć soroków soboli, trzy białozory, żywą kunç i sobola, o tyle król otrzymał za pośrednictwem posha tylko pierściéí zloty, kosztownie oprawiony luk, konie: nalıajskiego i perskiego, dwanaście soroków soboli, osiem marmurków i trzynaścic rysiów. Car nic był szczególnie zainteresowany w obdarowywaniu zlotem i drogimi wyrobami sztuki jubilerskiej polskiego monarchy, wyżej cenił bliskiego inu osobiście i oddanego calym sercem sprawie Jerzego Mniszcha. Natomiast Maryna otrzymala od męża: obraz przedstawiający Trójcẹ Swiętą, pierścicín zloty z dianentem, „zaponę ptaka" z osadzonymi w nim diamentem, rubinem i perłani, naczynie kamienne w kszalcie zwierzęcia ze zlotymi skrzydłami, hiacyntową czarę̧ oprawioną w złoto, srebrnego pelikana,

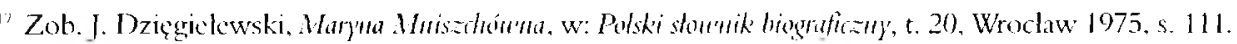

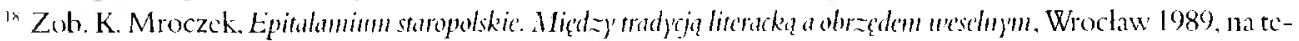
mat utworu (Grochowskicgo: s. 87-89: zaś o tekścic Jurkowskicgo s. 73-74. Z prac monograficznycl nalezy

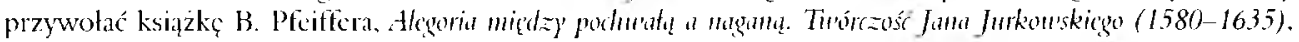
Wroclaw 1995, s. 112 i nast. Niestety autorka osobncgo opracowania poświęconego twórczości okolicznościowej S. Grochowskiego nic poświęcila micjsca przyuolanenut tu1 ntworowi - zob. A. Oszczęda. Pocta Wazón.

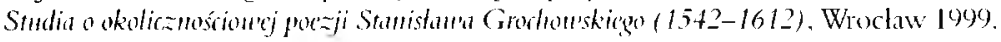


jelenia z Dianą na grzbiecie, okręt ze srebrnym pawiem, zegar na słoniu, wyroby sukiennicze: czerwony wenecki aksamit, zlocisty attas, jedwab czerwono-biały oraz srebrno-zloty, atłas ze srebrnym spodem oraz cztery jeszcze inne odmiany tej materii, bialy altembas, trzy rodzaje aksamitu, trzy soroki soboli oraz dużą liczbę perel. Można z całym przekonaniem stwierdzić, że dary, jakic dostala Maryna, byly znacznic bogatsze niż te, które przywiózł posel dla króla i ojca carskiej małzonki, a przy tym stosownie dobrane do upodobań i kobiecych potrzeb (z dużą liczbą materiałów na suknie oraz ozdobnymi wyrobami sztuki jubilerskiej). Zwraca uwagę liczba zwierząt uwiecznionych w zlocie. Ten zespól przedmiotów jawi się jako paralela dla wprowadzonego w Marsie moskieuskinn wyliczenia gatunków wschodnioeuropejskiej fauny zasiedlającej moskiewskie puszcze. Opis darów odbiega także od standardu suchego wyliczenia, jakim posłuzył siç poeta, wymicniając przedmioty przysłane dla Zygmunta III oraz Mniszcha. Szczególnie uwage Zabczyca przyciągnąl zegar, nie tylko z powodu swego wyglądı w stanie spoczynku, ale przede wszystkim w związku z zamiarem podkreślenia jego zmian w ruchu:

Zatym zegar na słoniu, w którym sluczna sprawa

Zamykała siç kunsztów. (idy bil, to trąbili

Trębacze, w regał grali, a drudzy się bili. (k. A 4 r.)

Znajomością bogatej palety kolorów popisal się poeta, wyliczając tkaniny przeznaczone na szaty:

Atlas zlocisty na brzegach, a jedwab czerwony

$Z$ bialym: atlas dno srebrne, w nim miesiąc, korony

Sute z różnych jedwabiów mając, atlas na lazurze

Wszelkich jedwabiów mając, rozwad w zlotej szmurze.

Atlas na dnie czerwonym ze zlotem robiony,

Atlas zólty, duo biale, bialy i czerwony

Jedwab srebro ze zlotem łączyl, nicią rzadki

Altembas potym dawal bialy, srebrem gładki (k. A 4 l:-B).

Najbardziej istotnym darem, według Zabczyca, stały się perly. Powiedział o nich w części wieńczącej wyliczenie, szczególnie podkreślając wagę i rozmiary kamieni:

Na koniec perly oddał, tych waga niemala

Cztery tysiące lotów ośmnaście siągala,

Byly drugie tak wielkie, ize się równaly

Żolędzi, jeśli jeszcze ich nie przewyższaly (k. B).

Podarunki powędrowały także w przeciwną stronę. W końcowej partii poematu wyliczył twórca przedınioty of iarowane carowi przez króla i królewicza, matkę panny mlodej i jej babkę. Przekazanic ich uzasadnił autor dość przewrotnie, jakby zapominając, iż przywołana zasada dziala w dwie strony: 
Daje łańcuch ze zlota, daje roztruchany,

A tym samym niewoli cne moskiewskie pany (k. B 3).

Obok opisów dárów, zreferowanych mów postaci, znalazło się miejsce dla zapisu zachowań etykietalnych. Zabczyc wyliczył dostojnycl gości, którzy zaszczycili swą obecnością ślub Maryny, nazwanej „Mniszchowym klejnotem”. Przekazanie jej osoby carowi miało zrównoważyć wartość podarków złożonych królowi, ojcu i rodziniè. Poeta odnotował obecność na ślubie i udział w uroczystościach weselnych króla z królewiczem Whadysławem, królewną, legata papieskiego i zbiorowo senatorów. Upaniçtnił taniec carowej z Zygmuntem III, królewiczem Wadysławem oraz panami polskimi. Warto podkreślić, ze krótki ten fragment przynosi opis tańca stanowiący dowód dązenia do zatrzymania w świadomości odbiorcy przepychu i wspanialości dworskiej zabawy. Obok charakterystyki darów prezentacja tańca to kolejna próba wprowadzenia do informacyjnego przekazu elementu ówczesnego rytuału dworskiego w postaci literackicj fotografii, której znaczenic propagandowe polegało równiez na wyliczeniu osób biorących udzial w rozbawionym korowodzie:

Wprzód od króla polskiego wiedziona Carowa,

W tance kolem toczone; gdzie stuzbę gotową

Oddał ojcu królewic, w onym ślicznym kole;

Potym i san, dając cześć dobromyślnej szkole,

Wiódł na plac tymże trybem senatorska corę

Whadystaw, dziedzic polski, gdzie skokiem pozorę

Ponowil wszytkiem milą, a temu służyli

Potentatowie polscy, i wańcu pluzyli (k. B).

Podobnie etykietalno-propagandową funkcję pehniło wprowadzone wcześnicj wyliczenie osób zasiadających za stolem. Sklad nie różnił się zbytnio od uprzednio podanego: obok rodziny królewskiej z królewną szwedzką także legat papieski, czlonkowie poselstwa moskiewskiego i znowuż zhiorowo polscy senatorowie. Uwzględnić trzeba dodanie wspomnianego wcześniej również kardynala Bernarda Maciejowskiego, który udzielal ślubu.

Okazjonalny dworski charakter maja takze mowy przypisane kolejnym oratorom; one równiez zostaly zbudowanc i dobrane stosownie do godności wygłaszających je osób. Końcowe strony poematu przyniosly wezwanie do zaniechania waśni, wyliczenie tego, co nalezałoby czynić, by poprawić stosunki miçdzy państwami:

Bo juz czas przestać placzów; czas zetrzeć dumania,

Czas poniechać lannentów i smutnego lkania.

Czas zapomnieć kopijej i artownej zbroi

Czas wymierzyć zlą trwogę; a koń niech zostoi

Micjsce u swego żlobu, bo juz czas pokoju

Nadszedł, wraca siç już Mars od krwawego zdroju (k. B 2). 
Żabczyc ogłosil więc w Pośle moskienskim nastanie czasu pokoju po burzliwych zdarzeniach pierwszej Dymitriady. Wiadomo, że jego optymizm był przedwczesny. Zapowiedział powrót z wojny, oczywiście, Marsa sarmackicgo, nie przewidział, że do działań poderwie się moskiewski Mars.

Szczególnym uhonorowaniem rodziny Mniszchów było podkreślenie nowych parenteli, jakie zyskiwali poprzez malżeństwo córki. Krótki ten fragment był najwyraźniejszym ukłonem poety w kierunku mecenasów. Odbiorca miał się przekonać, że związek z Moskwą to nie tylko korzyści dla calego państwa, lecz również poprawa prywatnego polożenia jednego z ubogich senatorskich rodów, który mial pretensje do zajęcia lepszego miejsca w senatorsko-magnackiej hierarchii Rzeczypospolitej.

Przedstawione w utworze niejednorodne przeciez wydarzenia ujął autor w klamrę kompozycyjną, którą stanowiła wizyta Afanasija Wlasiewa. Znalazły się bowiem informacje o przybyciu poselstwa, kilku odległych w czasie i przestrzeni spotkaniach, zaślubinach i weselu - a więc wątek epitalamijny - jak też o nadziejach, jakie wiązano w Rzeczypospolitej z małzeństwem Maryny, aż po wyjazd posła. Utwór wzbogacają oracje, zdobią opisy darów, migawkowe relacje o przebiegu ważnych wydarzeń (zaślubiny), szkicowo utrwalone dla współczesnych i potomnych elementy ceremoniału dworskiego. Calość służyla skrótowemu, ale i artystycznie przennyślanemu pokazaniu tego, co stanowiło konsekwencję objęcia tronu moskiewskiego przed Dymitra; wypowiedź miala zachęcić nieprzejednanych przeciwników awantury moskiewskiej do poparcia, zdawać by się moglo, zakończonej powodzeniem interwencji. Poset moskie'uski pelnił więc również rolę informacyjno-propagandową, napisany został jako realizacja dobrze zaplanowanego zanysłu artystycznego. Opis poselstwa pozwolił uchwycić nie tylko cząstkowe zdarzenie w postaci zaślubin, lecz równiez cały bardzo istotny kontekst zabiegów dyplonatycznych, które wspomagaly realizację tego zanyshu, a ponadto, co bardzo istotne, jeśli nie najważniejsze, pokazać w końcówce utworu korzyści, jakie mogła odnieść Rzeczpospolita nie tylko z samej misji Wlasiewa, lecz z calego bardzo ryzykownego przecież przedsięwzięcia moskiewskiego. Podkreślmy jeszcze raz, że funkcji propagandowej wypowiedzi towarzyszyla doskonale ponyślana, urozmaicona i dynaniczna kompozycja poemaciku. Poset moskieu'ski Zabczyca to nie dzieto przypadkowe, ale rzetelnie wykonana robota pisarza o ambicjach propagandysty i artysty.

Pobudka boginna to pieśni pochwalna stanowiąca swego rodzaju dodatek do Posta moskicu'skiego, mająca na celı oddanie szczególnego hołdu moskiewskiemu wladcy, jak też jego świeżo poślubionej małżonce. Punkt wyjścia dla słów poety stanowi apostrofa do Muz, mająca zwrócić uwağę najpierw na uroczystą ucztę weschną, późnicj zaś na osobę samego adresata pieśni. Dopowiada ona to, czego nie mógl pomieśsić poeta, zachowıjąc dyscyplinę kompozycyjna, w Pośle moskicuskim - mają̧a wiele wspólnego z konwencjami poezji weselnej pochwalę państwa młodych, w tym wypadkı również pary panıjących w sąsjednim państwic: 
Wierszem, Kanneny, milym zaśpiewajcie,

Slawną biesiadę miądrze wyslawiajcic.

Dając cześć dzisia domowi zacnemu.

Czaru możnemu.

Ten to jest bowien, który cnót dzielnościa

Przechodzi wielu, w rzeczach potocznością,

Tego wy sławcie, dzisia mile glosy,

Aż pod niebiosy (B 3v).

Zabczyc clıwalił w kolejnych strofach, oczywiście na wyrost, sławę wojenną Dymitra, o której przekonać się mieli już sąsiedzi, jak też inne cechy, opisywane przy pomocy odwołania do symboliki mitologicznych imion postaci: mądrości patronowal Sokrates, męstwu i dzielności Achilles oraz Atena, chowany był Dynitr na Olimpic, kapany w „wodzie kastalijskiej”, zaś karmiony „potrawy Febusowymi”. Ulubieniec bogów zostal także przez nich szczęgólnie obdarowany. Jowisz dal mu urodę, Mars męstwo, natomiast Apollo mądrość, Minerwa cnotę. Stąd też, jak zauważył autor, slusznnie należy siç Dymitrowi pochwała, szczególny honor i specjalne posługgi: natarcie skroni ziołani z Parnasu, polożenie na czole wieńca z liści laurowych, drogi ubiór ( „kosztoświetnący”), cenny lańcuch, złoty pierścień z diamentem. Zabczyc życzył również Dymitrowi, by stal się pupilem Jowisza zarówno w Rusi, jak i w calej Europie, a więc, by by otaczany szacunkiem jako whadoa w swoim kraju i za granica (strofa 14). Wybranicy bogów potrzeba bylo także przychylności Wenery, by mógł znaleźc dzięki czynnościon postaci z jej orszaku odpowiednią kandydatkę na żonę, z która spędzi szczęśliwie resztç życia. Poeta określil wymagania, jakie stawiano takiej kobiecie: powinna być równa stanem, wywodzić się ze sławnego, szanowanego domu i cechować się wiennością. Końcowy fragment Pobutki to pochwala domu Mniszchów i samej Maryny za urodzenie, cnoty domu, urodę, kosztowny ubiór, posturę i dobrą opiniç (strofa 20). Dopełnicnic pochwaly carowej stanowią porównania córki Jerzego Mniszcha do słynnych postaci antycznych i mitologicznych:

Adrasta króla. przechodzi Argija.

A w darskość rzeczy slawną Lukcecyją.

Jowisza córka z Feben wespót rodna,

Cyntia ozdobna.

Nie ma nic przed nia, ani w obyczaje

Ona celuje, bowiem jej dodaje

Juno wszytkiego, z pokolenia cnego,

Jowiszowego $\left(\mathrm{k} . \mathrm{B}+\mathrm{u}^{\prime}\right.$ ).

Pobudkę kończą życzenia dla mkodej pary nicopatrzone mitologicznym sztafażem, przynoszące natomiast prośhę o opiekę Boga clırześcijańskiego. Pieśń skonstruowana zostala zatem z myślą o Dymitrze i Marynie, poeta jednak przyjął jako dominującą perspektywę młode- 
go cara, podejmując pochwałę jego żony w końcowcj części wiersza. Slawienie cnót Maryny podporządkowane zostato interesom monarchii moskiewskiej. Córka Mniszcha stała się niezbędną cząstkią szeroko ponyślanego planu panowania Dymitra, stąd też jej postać, dla zachowania odpowiednich proporcji podyktowanych etykictą dworską, zeszla w panegirycznej Pobudce na dalszy plan.

\section{Żegnanie ojczyzny możnej cesarzowej moskieuskiej}

Wypowiedź sklada się z dwóch części, tytulowego Żegnania ojazy'zn' oraz dolączonego na końcu, krótszego juz Winczon'ania Polski. Obie części okolicznościowego poemaciku napisane zostały strofą saficką, co ma ilustrować liryczność zamystu autora".

Zabczyc rozpocząl utwór bezpośrednim zwrotem do Wenery, którą oskarżył o to, że zburzyła przybyciem Dymitra pokój domu Mniszchów. Pierwsze słowa owej inwokacji bliskie są konwencji cpicedialncj, ponieważ wyjazd Maryny do odlegtej Moskwy w praktyce oznaczal, że rodzice nie będą mieli okazji więcej jej zobaczyć, stąd też ojcięc i matka ukazani zostali tak, jakby za sprawą Wentery znaleźli się w żałobie:

Śliczna Cyprydo, coś to uczynita?

Na czyıneś prace swoje zasadziła?

Ojca sierocić pragniesz z córą świętą

Cnotami wziętą.

Chcesz macierzyńskie usta zlać płakaniem,

Pragniesz nabawić powinnyclı troskaniém,

Dając MARYNE w dalckic krainy

Cudze dziedziny (k. A 2).

Tonacja funeralna powróci jeszcze w końcowej części utworu, gdy Maryna żegnać będzie czlonków rodziny oraz dostojników Rzeczypospolitej.

Wyrzuty poety pod adresem Wenery dosiçgły takze jej wplywu na przybycie Dymitra:

Ślesz swe potomstwo w kraje pograniczne,

Tym wiedziesz męża przez troski rozliczne,

Stawiasz go smutnym w senatorskich gmachach

W Mnischowych dachach (k. A 2).

Jego pojawienie się stanowić miało główną przyczynç zamętu, który zatrząsl nie tylko domem Muiszchów, ale i całą Rzecząpospolitą. Płomień Cyprydy aczynić mial bowiem ze starca, Jerzego Mniszcha, mlodzika, który siadł na koni, by udać się na wojnę o tron dla przyszlego zięcia. Ojciec Maryny porzucil dla tej sprawy swe stateczne życie, opuścił dom i rodzinç, przypasal broń po to, by siać spustoszenie w obcym kraju.

I" Por. uwagi J. Nowaka-Dluzewskicgo, op. cit.. s. 194-195, a takze T. Banasiowej. op. cit. s. 62-67. 
Poeta zaznaczyl, że Mniszech podjąl się misji nie bez pomocy Boga. Stwórca winien byl go wspomagać, jako poleconego swojej opiece. Wojewoda poświęcić się mial, zdaniem poety, słusznej sprawice, ,przywracając państwo dziedzicu własnemu” (k. A.2 l.), czyli osadzając na tronic prawowitego monarchę.

Kolejne strofy przyniosty sygnały zmagania się wojewody sandomierskicgo z przeciwnikami krytykującymi podjęcie przez Mniszcha interwencji w Moskwie. Owym zoilusom, jak cheial Zabczyc:

Zamknąl inn mowę i kly wyostrzone

Start swym przyjazdem (k. A 2 v.).

Wykonanie zadania z. powodzeniem, militarne sukcesy Dymitra w drodze do Moskwy, zakończyć mialy seriç wystąpień oponentów Mniszcha oraz przeciwników interwencji w Wielkim Księstwie. Nie dowierzali oni jednak do końca docierającym do Rzeczypospolitej pomyślnym wiéściom. Dopiero przybycie kozackiego putkownika Swierskiego położyć miato kres dyskusji (k. A 3) oraz zapoczątkować seriç tryumfahnch uroczystości. Potwierdzenie pierwszej informacji stanowito przysłanie kolejnego poslanica, Lipnickiego, przybylego z nowiną o szczęśliwym objęciu tronu przez Dymitra (fakt ten symbolizowal wjazd do stolicyk. A 3).

Dalsze strofy utworu stanowią relację o kolejnych ctapach przebiegu zdarzeń, które dokonywały się w rytmic trwającej nieustannie wymiany informacji przy udziale następnych wyliczonych z nazwiska wysłanników (k. A 3 r). Zaprezcntowany sposób przekazu shuzyl jego kondensacji. Pretekstem do zmiany konwencji narracyjnej stala się wzmianka o przybyciu sekretarza carskiego (Buczyiskiego) do Rzeczypospolitej z misja przewiezienia do Moskwy świezo poślubionej carowej. Od skrótowego relacjonowania wypadków przeszedl poeta do wyliczenia bogatycl darów, jakie car kazal ofiarować Marynie, co zajęlo sicdem strof (k. A 4-A $4 \%$.).

Nadszedt też wreszcie noment pożegnania carowej z rodziną. Poeta utrwalil jej zachowanic, obrazujące nicnajlepszy stan ducha córki Mniszchów. Nieuchronnemu rozstaniu towarzyszyly lzy, świadomość niepewnego losu w odległym kraju kultywującym odmienme obyczaje, jak też obawa powierzenia whasnego bytu aż do końca swoich dni wylącznie matżonkowi. Poeta jednak dawal do zrozumienia, ze zgodnie nawet z Bibliq młodzi ludzic maja opuszczać rodziców i lączyć się ze sobą, tworząc nowe małżeństwa. To zalecenie wydało siç carowej niemite:

Przykre się zstawa jej już z Pisma zdanic,

Ze ojca, matkę opuścić, a kochanie

W małżonku tylko pokladać, przez lata

Pok zstanic swiata (k. B).

Marynę przenikała tęsknota za rodzicami, których miała już więcej nie oglądać. Smutck stanowi dominantẹ kompozycyjną tej części wiersza: 
Smutny to rozjazd, opuścić rodzice,

A dać ostatnie w żegnaniu prawice,

Dziękując za chęć i za wychowanie,

Smutue zegnanie (k. B).

Ciag dalszy to nostalgiczna wypowiedź Maryny ${ }^{2 n}$ żegnającej kolejno: ojca, powinowatych, krewnych, matkę, babkę, braci i siostry, slugi — dwór Mniszchów, wreszcic króla, radę królewską, dostojników świcckich i duchownych hierarchów i zakonników, ponadto „ojczyste mury i dachy”. Carowa dostrzegała w swoim losie dzialanie przeznaczenia, które skierowało ją w obce kraje (k. B). Myśl ta obecna była w stowach adresowanych do ojca, jak i do matki.

Pomnicież na mię modtami swoimi,

Bym Kościolowi mogla pociesznymi

Być filarami, a Koronie zgodą,

Każdą przygodą.

Pomnicież na mię szczerymi chęciami,

Ja wam shużý chcę życzliwie shuzbami,

I nie przepomnię $w$ cesarskim palacu,

Na kożdym placu (k. B 2 v,-B 3).

Poetycka oracja Maryny zdaje się zbliżać do konwencji pożegnania zmarlych ${ }^{21}$ spotykanego w mowach pogrzebowych. Wypowiedzi te należaly do struktury kazania i formulowane byly przez mówców duchownych. W pożegnaniach zmarlych zachowywano wynikającą z sytuacji i uzasadnioną kontekstem etykiety towarzyskiej kolejność osób, z którymi zmarly siç żegnal. Tu również obowiązywala hierarchia podporządkowana naczelnej wytycznej, którą stanowiło umieszczenie w pierwszej kolejności najblizszej rodziny, dalej zaś dopicro dostojników państwowych. W przypadku Zegnania ojzzyny orację wygłaszać miala, co zrozumiate. sama Maryna. Słowa wypowiadane były w zwrotnym momencie jej życia, w chwili przejścia spod opicki rodziców pod opiekę męża. Być może realizowana byla w tym wypadku konwencja mów pożegnalnych, stanowiąca element obrzędu weselnego ${ }^{22}$.

Dodatek do Żegnania... i zarazem odpowiedź na orację Maryny stanowiło IVinczon'anie Polski. Upersonifikowana ojczyzna żegnała swoją córkę, oplakiwala utratę tej, która — porównana do kwiatı rosnącego w ogrodzie - miała shızyć Bogu w Polsce (jako zakonnica),

\footnotetext{
"Jest ona drugim nadawą komunikatu po poccie i obok prozopopci ojczyzny (por. T. Banasiowa, op. cit., 5. 64).

"1 Por. tez T. Banasiowa. op. cit. . s. 6.3-64:... [unxór ] napisany zostal w tej samej konwencji, co liryczne pożegnania ze światem duchów zmarlych. wystçpujące w licznych sicdemmastowiceznych cyklach funcralnych $[\ldots]^{\prime \prime}$.

N Niestety nic zachowaly siç przyktady tego typu oracji we wzornikach mów weschych, brak ich również w oracjach pozost.lych w formic rękopiśniennej. Uprzcjunie dziękııję za wiadomóś w tej sprawic Paniom dr Marii Barlowskicy oraz mg̣ Malgorzacic Trębskicj.
} 
bądź poślubić rodaka, będąc przykładem cnotliwego życia. Tymczasem los chcial inaczej; Maryna uszcz.upliła polski ogród swym zamążpójściem za cara. Ojczyzna bolata nad utratą córki, z której postawy przykład mieli brać duchowni oraz pokorne panny. Poeta uznal, że odejścic Maryny to zdarzenie naturalne, wynikające z woli Boga. Konstatacja ta kończy lamentacyjną część wiersza, zapoczątkowıje natomiast serię napomnién udzielanycl wyjeżdżającej. Miała dochować wierności wierze katolickiej, przestrzegać przykazań, żyć pobożnie, dążąc do zachowania jedności wiary, a więc i do zaprowadzenia w Moskwie religii rzymsko-katolickiej, nie ufać szczęściu - miéć się stale na baczności, odrzucać pokusę pychy, bowicm człowiek pozostaje nieustannie w mocy Boga; postẹpować miłosiemie, być łaskawą, hojną dla ubogich; szanować slugi, unikać dworskich poclılebców, radzić siç mądrych. Wiersz dopetniają wyrażone w ostatniej strofie życzenia, by dalszej drodze Maryny towarzyszyło Boże błogosławieństwo, a pożycie małżeńskie zaowocowało potomstwem.

Zespół rad, których udziclila Polska swej córce, wyznaczał programowo drogę nowego, dworskiego i osobistego (moralnego) życia. Przestrzeganie podanych reguł zapewnić miaho szczęście i bezpieczne życie wyjeżdżającej. Jest to zarazem (być może) próba zmierzenia się z przywarami Maryny. O ile wiçc slowa dotyczące jej wzorowego życia w cnocie w czasic pobytu w Polsce maja konwencjonalny charakter, o tyle $w$ długiej serii rad kryje się prawda o usposobicniu i upodobaniach przyszłej carowej. Wydaje się, ze Winczou'anie'... to przystowiowa lyzka dziegciu w beczec miodu.

Zwraca uwag̨ę wysoka jakość poetyckiej roboty. Poeta nie starał się już jedynie zapelnić nieudolnie wersów. Jego wiersz płynnie wpasowıje się w rozmiary strofy safickiej, często pojawiają się przerzutnie, które sprawiają, że nadrzędne znaczenie nna tok rozumowania i sens wypowiedzi, nie zaś forma.

\section{Zakończenie}

Zabczycowa trylogia to zróżnicowana formalnie opowieść o szczçśliwym przebiegu pierwszej Dymitriady. Znalazlo się tu miejsce i dla matej epiki bohaterskiej, i dla inkrustowanej opisem składanych darów oraz wygłaszanych mów relacji z przebiegu poselstwa Wlasiewa, jak też nostalgicznego lamentu-pożegnania ojczyzıy, któremu towarzyszyły zarazem życzenia szczęśliwej przyszlości oraz króthi poradıik życia dworskiego.

Zegnając carową Marynę, nie spodziewano się, że wkrótce po ślubie jej małżonek zostanie zamordowany, a ona „rozpozna” zabitego w innym młodzieńcu, by z nim razem podjać ponownie próbę zapanowania w Moskwie. To „cudowne rozpoznanie” i uznanie innego za poprzednio poślubionego męża przyczyni się do zmiany postawy spoleczeństwa polskiego wobec Maryny. Z szanowanej, nieco może wynioslej carowej, zmieni się w oczach opinii publiczncj w kobietę gotową z żądzy wladzy poświęcić wlasną czešć i splamić honor. Postawa Maryny stała się tak ewidentna, ze określenie opowieści o jej losach znalazło swój final w zwrocie przysłowiowym: "gadać o dupic Marynie” nienotowanym w Noucjksigdze przystón" polskidh. Na sprawę zwrócił uwagę Tadeusz Ulewicz wartykuliku O najstarszyd i póámiejsz)d 
zapożyczeniach jez)kourych ur Polsce: glosa historyczno-kulturalma ${ }^{23}$. Przyslowie to, jak też późniejsze czyny carowej, doskonale korespondują z poradami, jakich udzielał wyjeżdżającej Zabczyc. Niestety, nie poshuchała ona shugi — nadwornego poety swego ojca. Jej postawa, zdominowana żądzą whadzy i pychą w niesprzyjających również okolicznościach zewnętrznych, doprowadzila nie tylko do utraty wpływów, które Maryna chciała zatrzymać za wszelką cenę, ale i do upadku moralnego - czego jej spoleczeństwo nie wybaczyło.

W Żabczycowej trylogii brak jednak jeszcze choćby cienia tego, co przyniosła nieodlegha przyszłość. Poeta utrwalił w świadomości spolecznej osobisty sukces i tryumf Mniszchówny, pokazal czytelnikowi pierwszych lat XVII wieku przyklad niemającej precedensu karicry kobiety, która u boku swego równic ekspansywnego małżonka postanowila radykalnie odnnienić whasny los, jak też podjąć próbę wplynięcia na bieg historii stosunków między Rzeczą̧ospolitą a Moskwąa. 